\title{
DESAIN PEMBELAJARAN BAHASA ARAB BERBASIS PENANAMAN KARAKTER UNTUK ANAK USIA DINI
}

\author{
Akla \\ Institut Agama Islam Negeri Metro \\ Jl. Ki Hajar Dewantara 15A Iring Mulyo Kota Metro \\ Email:akla.hasan@gmail.com
}

\begin{abstract}
Early childhood is the most important time for development, so early childhood is in the stage of growth and development of the most rapid both physically and mentally. Brain development as a center of intelligence occurs very quickly because brain development in early childhood has reached 80 per cent of adults so that period is called the golden age. So that educators should consider the characteristics of the students so that the learning plans in accordance with aspects of child development. One aspect of development that must be developed is the language. Language has an important role in the development of children by using the language of children will develop into adult human who can socialize with people who are environment. After the first language or mother tongue is ripe, the early child can learn a second language. With this condition then becomes the rationale why the learning of Arabic should have started taught in early childhood by not forgetting the inculcation of the value of the characters inside. By way of designing the development of language learning includes needs analysis, goal form, syllabus design, methodology, test and evaluation. Then designing language learning based on the planting of early childhood characters with activities of playing, singing, storytelling or storytelling, drawing and sign patterns.
\end{abstract}

Keywords: learning design, Arabic language, character, early childhood

\begin{abstract}
Abstrak
Anak usia dini merupakan masa yang tepat untuk perkembangan, sehingga anak usia dini sedang dalam tahap pertumbuhan dan perkembangan yang paling cepat baik fisik maupun mental. perkembangan otak sebagai pusat kecerdasaannya sangat cepat karena perkembangan otak pada anak usia dini telah mencapai 80 prosen dari orang dewasa sehingga masa itu disebut sebagai zaman keemasan. Begitu pendidik harus memperhatikan karakteristik anak didik agar sesuai pembelajaran sesuai dengan aspek perkembangan anak. salah satu aspek yang harus dikembangkan adalah bahasa. Bahasa yang memiliki peran penting dalam perkembangan anak dengan menggunakan bahasa anak akan berkembang menjadi manusia dewasa yang bisa bersosialisasi dengan orang-orang yang berada dilingkungannya. Setelah bahasa pertama atau bahasa ibu sudah matang matang, maka anak usia dini bisa belajar bahasa kedua. Dengan kondisi inilah maka menjadi dasar pemikiran mengapa bahasa inggris sudah mulai diajarkan pada anak usia dini.
\end{abstract}


Dengan cara mendesain pengembangan pembelajaran bahasa kebutuhan, bentuk tujuan, desain silabus, metodologi, tes dan evaluasi. Lalu mendesain pembelajaran bahasa anak dengan cara bermain, bernyanyi, mendongeng atau bercerita, gambar dan pola tanda.

Kata kunci: Desain pembelajaran, bahasa Arab, karakter, AUD.

\section{Pendahuluan}

Kesadaran akan kebutuhan penguasaan bahasa Arab kini cenderung meningkat sejak ditetapkankan bahasa Arab sebagai bahasa Internasional. Selain bahasa Internasional, bahasa Arab merupakan alat untuk memahami ajaran agama dari sumber asli berbahasa Arab disamping menguasai praktik agama seperti shalat dan membaca al Qur'an. Untuk kepentingan ini maka penguasaan bahasa Arab bagi setiap orang menjadi sebuah keniscayaan. Agar dapat menguasai bahasa Arab secara optimal, maka bahasa Arab dimasukkan kedalam kurikulum pendidikan baik formal maupun non formal mulai dari pendidikan dasar sampai pendidikan tinggi. Beberapa pakar menyatakan bahwa penguasaan bahasa Arab sebaiknya mulai diajarkan pada anak usia dini. Pertimbangannya adalah pada masa usia dini merupakan periode awal yang paling penting dan mendasar di sepanjang rentang pertumbuhan dan perkembangan kehidupan individu. Salah satu periode yang sangat penting sebagai periode emas (golden ages). Periode emas ini merupakan semua potensi anak berkembang paling cepat. Hasil penelitian di bidang neurologi mengatakan bahwa $80 \%$ kapasitas kecerdasan anak terbentuk dalam kurun waktu empat tahun pertama sejak kelahirannya. ${ }^{1}$ Kondisi inilah kemudian menjadi dasar pemikiran mengapa pembelajaran bahasa Arab sebaiknya sudah mulai diajarkan pada anak usia dini.

Karakteristik bahasa Arab yang unik, yang tidak dimiliki oleh tatanan bahasa Indonesia menjadikan kejelian dan kehatihatian dalam mendesain dan mengembangkan pembelajaran bahasa Arab untuk anak usia dini. Pada aspek bunyi bahasa Arab sebagai salah satu rumpun bahasa Semit, memiliki ciri-ciri khusus yang tidak dimiliki bahasa lain, terutama bila dibandingkan dengan bahasa Indonesia seperti vokal panjang, bunyi tenggorokan, bunyi tebal dan bunyi bilabial dental . Pada aspek kosakata, bahasa Arab menganut pola pembentukan kata yang sangat fleksibel, baik melalui derivasi atau dengan cara infleksi. Dari aspek kalimat, bahasa Arab adalah bahasa yang memiliki sistem i'râb terlengkap yang mungkin tidak dimiliki oleh bahasa lain. I'râb adalah perubahan bunyi akhir kata, baik berupa harakat atau pun berupa huruf sesuai dengan jabatan atau kedudukan kata dalam suatu kalimat. I'râb berfungsi untuk membedakan antara jabatan suatu kata dengan kata yang lain yang sekaligus dapat merubah pengertian kalimat tersebut. Dan dari aspek huruf, bahasa Arab memiliki ragam huruf dalam penempatan susunan kata, yaitu ada huruf yang terpisah, ada bentuk huruf di awal kata, di tengah

1 Ahmad Susanto, Perkembangan Anak Usia Dini; Pengantar dalam Berbagai Aspeknya ( Jakarta: Kencana Prenada Media Group, 2011) h. 22 
dan di akhir kata dan setiap satu huruf hanya melambangkan satu bunyi.Cara penulisan berbeda dengan penulisan huruf Latin, yakni dari arah kanan ke kiri. Keunikan-keunikan ini kemudian menjadi pertimbangan dalam mendesain pengembangan pembelajaran bahasa Arab anak usia dini, disamping mempertimbangkan karakteristik anak usia dini.

Keunikan bahasa Arab diatas mengharuskan guru lebih teliti dalam mendesain pembelajaran bahasa Arab untuk anak usia dini. Dalam mendesain pembelajaran tentu tidak hanya memuat aspek bahasa, namun perlu dipertimbangkan aspek-aspek lain seperti penanaman karakter mulia. Karakter mulia dapat diinternalisasikan melalui muatan-muatan akhlak dalam pembelajaran bahasa. Tujuannya selain memiliki penguasaan bahasa Arab, anak juga dibekali dengan nilai-nilai karakter mulia. Tulisan ini akan memaparkan desain pembelajaran bahasa Arab untuk anak usia dini dengan menginternalisasikan nilai-nilai karakter.

\section{Pembahasan}

Bahasa merupakan alat untuk menyatakan perasaan, pikiran, harapan, permintaan kepada orang lain. Bahasa mempunyai peran penting dalam perkembangan anak dengan menggunakan bahasa anak akan berkembang menjadi manusia dewasa yang dapat bersosialisasi dengan orangorang yang berada dilingkungannya. Anak adalah sebagai peniru (iminator) orang lain, jadi segala macam di dalam aspek bahasa harus diperkenalkan kepada anak karena hal ini merupakan dasar untuk perkembangan bahasanya. Dimana periode sensitif terhadap bahasa berada dalam usia 0-8 tahun.

Unsur-unsur bahasa tidak dapat dipisahkan dari aspek keterampilan bahasa terutama unsur bahasa kosakata. Karena kosakata memilki peran yang sangat penting dalam berbahasa. Makna suatu wacana sebagai bentuk penggunaan bahasa. Sebagian besar ditentukan oleh kosakata yang digunakan dalam pengungkapannya. ${ }^{2}$ Senada dengan) itu David Nunan mengemukakan bahwa "one of the most influential structural linguist of the day, when so far as to argue that vocabulary was the easiest aspects of language to learn and that it hardly required formal attention". ${ }^{3 S a l a h}$ satu struktural bahasa yang paling berpengaruh saat ini adalah kosakata, kosakata merupakan aspek paling mudah untuk mempelajari kosakata. Tanpa kosakata sesorang tidak akan dapat menggunakan struktur dan fungsi bahasa dalam berkomunikasi secara komprehensif.

Selain itu, Keraf dalam bukunya Diksi dan Gaya Bahasa memberikan penjelasaan bahwa penguasaan kosakata merupakan kesimpulan keseluruhan yang dimiliki oleh bahasa, dan kosakata seseorang. Keseluruhan kata yang berada dalam ingatan seseorang yang segera akan menimbulkan reaksi bila didengar atau dibaca. ${ }^{4}$ Pendapat yang serupa dikemukakan oleh Vacca dan Gove kosakata didefinisikan keseluruhan kata yang yang digunakan oleh

${ }^{2}$ M.Soenardi Djiwandono, Tes bahasa dalam pengajaran (Bandung:ITB, 2008), h. 43.

3 David Nunan, Language Teaching Methodology (New York: Prentice Hall, 1998), h. 117

${ }^{4}$ Gorys Keraf, Diksi dan Gaya Bahasa, (Jakarta:Gramedia,2000) h. 80 
seseorang dalam komunikasi. ${ }^{5}$

Dalam mengembangkan aspek bahasa pada anak usia dini perlu dirancang desain pembelajaran karena ini dapat membantu proses belajar anak. hal ini diungkapkan oleh Gagne dan Briggs bahwa desain pembelajaran dapat membantu proses belajar seseorang dalam waktu yang panjang. ${ }^{6} \quad$ Proses pembelajaran terjadi karen adannya kesiapan dan kempuan anak yang disebut dengan kondisi internal. Serta kegiatan pembelajaran yang harus didesain dan diaksanakan oleh guru yang di sebut dengan kondisi eksternal. Desain pembelajaran merupakan satu kesatuan dari beberapa komponen pembelajaran yang saling berinteraksi, interdependensi dan interelesasi dalam mecapai tujuan pembelajaran. komponen pembelajaran direncanakan dengan pembelajaran yang dikembangkan. Adapun komponen terdiri dari :

- Anak usia dini

Anak usia dini merupakan masa yang terpenting bagi perkembangan anak sehingga anak usia dini dalam tahap pertumbuhan dan perkembangan yang paling pesat baik secara fisik maupun mental. perkembangan otak sebagai pusat kecerdasaan terjadi sangat cepat karena perkembangan otak pada anak usia dini telah mencapai 80 prosen dari orang dewasa sehingga masa itu disebut sebagai golden age. Hartati

${ }^{5}$ Jo Anne L Vacca, Richard T Vacca \& Marry K. Gove, Reading and learning to read (Boston:Little Brown \& Company, 1987), h. 77.

6 Robet Gagne \& M. Leslie J. Briggs. Principles Of Intuctional Design, Second Edition ( New York : Holt And Wiston, 1979) h. 55 mengemukakan bahwa anak usia dini merupakan kelompok manusia yang berada dalam proses pertumbuhan dan perkembangan secara terus menerus. ${ }^{7} \mathrm{Hal}$ ini menandakan bahwa anak usia dini adalah individu yang unik dimana anak memiliki pola pertumbuhan dan perkembangan fisik, kognitif, sosioemosional, kreativitas, bahasa dan komunikasi.

- Karakteristik anak usia dini

Seorang guru atau pendidik harus memperhatikan karakteristik anak didik agar program pembelajarannya sesuai dengan aspek perkembangan yang meliputi bahasa, seni, nilai agama dan moral, sosial dan emosional, fisik motorik. Richard D. Kellough sebagaiman dikutip oleh Hartati mengemukakan bahwa karakteristik anak usia dini yang khas adalah: 1) Egosentris, 2) Memiliki curriosity yang tinggi, 3) Makhluk sosial, 4) The unique person, 5) Kaya dengan fantasi, 6) Daya konsentrasi yang pendek, dan 7) Masa usia dini merupakan masa belajar yang paling potensial. ${ }^{8}$ Anak-anak merupakan pribadi yang memiliki rasa ingin tahu yang besar dan sangat antusias terhadap banyak hal terutama hal yang dianggap baru oleh mereka.Dengan memperhatikan karakteristik anak, tujuan pembelajaran bahasa Arab berbasis penanaman karakter untuk anak usia dini dapat ditentukan sebagai berikut : 1) membuat anak merasa percaya diri dalam belajar

7 Sofia Hartati, How To Be a Good Teacher and To Be a Good Mother, (Jakarta: Enno Media, 2007), h.11.

${ }^{8}$ op. cit., h.12-17. 
bahasa Arab 2) menyediakan lingkungan pembelajaran yang aman, bersifat menghibur dan mendidik 3) menciptakan pembelajaran bahasa Arab berbasis karakter.

- Penanaman Karakter untuk anak

Penanaman karakter sejak dini merupakan periode paling tepat untuk pembentukan karakter seseorang karena masa ini merupakan masa Golden Age dimana masa belajar yang paling potensial. Sebab, anak sedang mengalami proses perkembangan dan pertumbuhan yang sangat luar biasa. Dimana orang tua dan pendidik akan lebih mudah dalam mengarahkan dan membimbing anak usia dini dalam menanamkan nilai-nilai karakter dalam kehidupan sehari-hari agar terbentuknya peserta didik yang yang berkarakter karena nilai-nilai karakter begitu penting keberadaanya.

Menurut pusat bahasa depdikmas pengertian karakter adalah hati, bawaan, keperibadiaan, jiwa, prilaku, budi pekerti, personalitas, watak, tabiat. ${ }^{9}$ Karakter melekat pada prilaku anak. sedangkan kemendiknas mengemukakan ada delapan belas karakter yaitu : ${ }^{10}$ Religius, jujur, toleransi, disiplin, kerja keras, kreatif, mandiri, demokratis, rasa ingin tahu, semangat kebangsaan, cinta tanah air, menghargai prestasi, bersahabat,/ komunikatif, cinta damai, gemar membaca, peduli lingkungan, peduli,

${ }^{9}$ Zubaidi. Desain pendidikan karakter : konsepsi dan aplikasinya dalam lembagapendidikan. (Jakarta: Kencasana, 2011) h. 8

${ }^{10}$ Pusat kurikulum departemen pendidikan nasional. Bahan pelatihan penguatan pembelajaran berdasarkan nilai nili-nilai budaya dan karakter bangsa. 2010 sosial dan tanggung jawab. Nilai-nilai karakter ini perlu di tanamkan sejak dini terutama dalam mendesain pembelajaran untuk anak.

- Karakteristik Pendidik

Pembelajaran bahasa Arab pada prinsipnya adalah suatu proses pemerolehan bahasa yang dilakukan secara sengaja dan bertujuan didalam proses pembelajaran. tugas pendidik bagi anak usia dini yaitu membantu perkembangan, pemahaman dan penggunaan bahasa melaui perencanaan, pembimbingan dan penyediaan sarana/ media penunjang yang memadai.

Dari segi kompetensi guru bahasa Arab untuk anak usia dini harus memiliki keterampilan dan kemampuan yang memadai. Karena penggunaan bahasa pertama atau bahasa ibu berbeda dengan bahasa Arab. Untuk itu mereka harus memahami 1) struktur atau tata bahasa Arab 2) kosakata dasar yang sesuai dengan kebutuhan perkembangan anak usia dini 3) ucapan atau pelafalan yang benar 4) intonasi atau tekanan yang benar 5) ejaan dan 6) kultur budaya bahasa Arab tersebut. Sehingga para pendidik harus memahami perkembangan anak usia dini dan hubungnnya dengan proses pembelajaran bahasa Arab berbasis penanam karakter. Agar dapat mendorong eksplorasi, perencanaan dan implementasi dalam pembelajaran bahasa Arab berbasis penanaman karakter sesuai dengan tujuan yang sesuai diharapkan.

\section{Konseptual Pengembangan Desain Pembelajaran Bahasa Arab}

Pembelajaran bahasa Arab sebagai 
bahasa asing sering dipandang dari perspektif yang sangat sempit, yakni sebagai tindakan mengajar guru. Oleh karena itu, ketika peserta didik tidak dapat mencapai suatu tujuan dalam pembelajaran, seringkali kegagalan ini dikaitkan dengan lemahnya metode mengajar guru atau kurang tersedianya media pendukung. Padahal sesungguhnya keberhasilan sebuah proses pembelajaran bahasa kedua akan sangat bergantung pada perencanaan pembelajaran yang matang mulai dari kurikulum, silabus dan bahan ajar dam evaluasi yang akan digunakan.

Oleh karena itu mendesain pembelajaran bahasa Arab dengan baik merupakan sebuah keharusan. Beberapa prinsip yang harus diperhatikan dalam mengembangkan pembelajaran bahasa yaitu: fleksibilitas, dari teks ke bahasa, pemakaian isi,bahasa alamiah, pendekatan analisis, menekankan pada pengulasan, praktik sesuai keinginan, keterampilan terpadu, pendekatan yang seimbang, pengembangan peserta didik dan penghargaan profesional". ${ }^{11}$ Pendapat ini memberikan gambaran bahwa dalam mengembangkan pembelajaran bahasa hendaknya menganut prinsip fleksibilitas. Fleksibilitas artinya materi ajar yang disajikan sesuai dengan kebutuhan peserta didik, karakteristik dan kemampuan berbahasanya. Materi ajar misalnya harus dimulai dari konsep teoretis yang kemudian diaplikasikan kedalam keterampilan berbahasa. Bahasa yang digunakan dalam membangun

${ }^{11}$ Brian Tomlinson, Developing Materials For Language Teaching (London,Cromwell Press, 2003) h.109 materi adalah bahasa ilmiah. Dalam kontek pembelajaran bahasa Arab maka bahasa yang digunakan adalah bahasa fushah. Struktur isi bahan ajar dibangun dari unsurunsur bahasa dengan menggunakan bahasa yang lugas dan mudah dipahami peserta didik. Pendekatan yang digunakan dalam penyampaian materi adalah pendekatan alamiah disesuaikan dengan karakteristik peserta didik yang dalam hal ini adalah anak usia dini. Materi ajar disusun dengan memperhatikan pengulasan yang tepat diiringi dengan latihan mandiri yang cukup - Tidak kalah pentingnya bahwa struktur pembelajaran bahasa disusun dengan memberikan ruang kepada peserta didik untuk melakukan latihan berbahasa sesuai keinginan, disamping penyajian materi hendaknya memperhatikan empat keterampilan berbahasa seimbang (mendengar, berbicara, membaca dan menulis). Pendekatan diarahkan pada proses belajar aktif .

Dalam melakukan pengembangan pembelajaran bahasa Richards menyarankan agar dimulai dari analisis kebutuhan. Model desain pengembangan pembelajaran bahasa bisa merujuk pada pola yang ditawarkan Richards digambarkan pada bagan berikut: ${ }^{12}$

12 Jack C. Ricard, Curriculum Development in Language Teaching, (New York, Cambridge University Press, 2001) h. 42 
Gambar.1

Desain Pengembangan Pembelajaran Bahasa

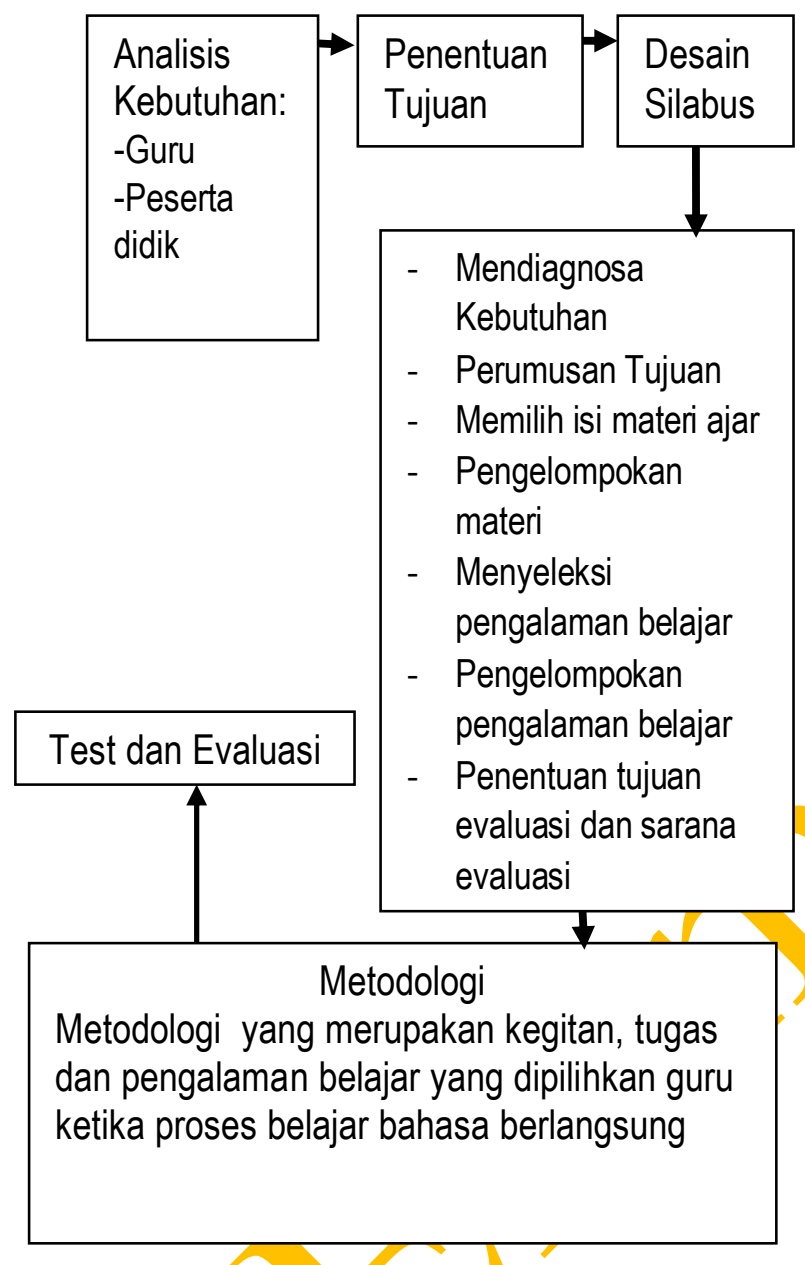

\section{a. Analisis Kebutuhan}

Dalam proses mendesain pembelajaran bahasa Arab, analisis kebutuhan merupakan salah satu tahap paling awal yang dilaksanakan. Hasil analisis kebutuhan ini selanjutnya akan menjadi dasar penyusunan kompetensi, materi ajar, strategi dan evaluaasi. Richard menyatakan bahwa analisis kebutuhan adalah : procedures used to collect information about learners needs". ${ }^{13}$ Analisis kebutuhan atau need analysis diistilahkan juga sebagai need assessment oleh Richard

${ }^{13}$ Jack C. Ricard, Curriculum Development in Language Teaching, (New York, Cambridge University Press, 2001) h.51 didefinisikan sebagai :... referst to an array of procedures for identifying and validiting needs an estabilishing priorities among them". ${ }^{14}$

Dari dua pendapat diatas disimpulkan bahwa analisis kebutuhan (needs analysis) disebut juga needs assessment merupakan kegiatan-kegiatan yang dilakukan dalam rangka mengumpulkan informasi yang digunakan sebagai dasar untuk menentukan konten bahasa dan proses pembelajaran untuk peserta didik,disamping untuk pengembangan model bahan ajar.Analisis kebutuhan merupakan aspek penting dalam menyusun sebuah desain model bahan ajar.

Analisis kebutuhan. adalah kegiatan membandingkan apa yang telah diketahui/kuasai dengan apa yang seharusnya mereka ketahui/kuasai. Dalam melaksanakan analisis kebutuhan, Nation dan Macalister menyarankan sebuah model yang didasarkan pada berbagai unsur yang diyakini membentuk kebutuhan peserta didik. Menurut mereka, kebutuhan peserta didik terdiri dari: (a) necessities: what is necessary in the leaners use of language? (b) lacks: what do the leaners lack? for example, are there aspects of writing that were not practiced in their previous learning? (c) wants: what do the learner wish to learn? ". 15

Kebutuhan (necessity) mengacu pada apa yang perlu diketahui dan dikuasai peserta didik agar dapat berfungsi dengan baik dalam situasi target. Kekurangan (lack) adalah ketimpangan antara situasi saat ini dengan situasi target. Keinginan (want)

${ }^{14}$ Jack C. Richard, The Language Teaching Matrix (New York, Cambridge University Press,1990) h. 1

${ }^{15}$ I.S.P. Nation and John Macalister, Language Curriculum Design ( New York; Routledge, 2010) h. 27 
mengacu kepada apa yang diinginkan oleh peserta didik untuk dimasukkan ke dalam proses pembelajaran. Hal ini didasarkan pada fakta bahwa peserta didik sedikit banyak mampu menentukan apa yang dirasa perlu untuk mereka kuasai. Oleh karena itu, pendapat peserta didik perlu dipertimbangkan dalam penyusunan suatu proses pembelajaran.

Dari tujuan di atas, dipahami bahwa analisis kebutuhan merupakan parameter umum suatu pembelajaran bahasa. Oleh karena itu dalam melakukan analisis kebutuhan disarankan untuk dua hal. Pertama analisis situasi. Analisis situasi adalah mengidentifikas kebutuhan dalam pembelajaran dengan merujuk kepada pertanyaan berikut : siapakah peserta didiknya?, apa harapan dan tujuan mereka?, gaya belajar apa yang mereka sukai?, secakap apakah para guru dalam bahasa target?, siapakah gurugurunya?, pengalaman dan pelatihan apa yang mereka miliki?, apa yang mereka inginkan dari program tersebut?, apa yang dimaksud dengan konteks administrasi program tersebut?, batasanbatasan (seperti waktu, biaya, sumber) apa yang ada?. ${ }^{16}$

Dengan mengacu kepada pertanyaan di atas dapat membantu pendesain dalam mengetahui apa yang dibutuhkan guru dan peserta didik, jenis keterampilan bahasa dan tingkat penguasaan bahasa yang harus diberikan dalam pembelajaran bahasa yang akan dikembangkan. Prosedur analisis kebutuhan menghasilkan sejumlah data yang dapat dipertimbangkan dalam

${ }^{16}$ Ibid h.2 mengembangkan bahan ajar, termasuk informasi tentang konteks program kebahaan, peserta didik, guru, dan faktor administratif yang mempengaruhi pembelajaran bahasa.

\section{b. Bentuk Tujuan}

Tujuan dari suatu kurikulum pembelajaran bahasa adalah pernyataan yang berisi hasil yang ingin dicapai dari suatu kegiatan pembelajaran bahasa. Dalam menyusun tujuan seharusnya didasarkan atas batasan-batasan yang ditetapkan berdasarkan analisis kebutuhan. Dalam menetapkan suatu tujuan pembelajaran bahasa menurut Richards ada yang dinamakan tujuan berbasis perilaku, berbasis ketrampilan, berbasis bahan ajar dan berbasis keahlian". ${ }^{17}$

Tujuan berbasis perilaku adalah tujuan yang disusun berkaitan dengan aspek-aspek keterampilan bahasa kedua yang dinyatakan sebagai kompetensi yang diharapkan dari peserta didik. Tujuan berbasis ketrampilan adalah tujuan yang disusun dengan merinci empat ketrampilan berbahasa seperti menyimak, berbicara, membaca dan menulis. Dalam menetapkan tujuan, diharapkan dapat mendeskripsikan kompetensi-kompetensi apa yang diharapkan dari perserta didik berkenaan dengan empat keterampilan bahasa tersebut.

\section{c. Desain Silabus}

Langkah ketiga adalah mendesain silabus yang akan digunakan. Dalam menyusun silabus dilaksanakan secara sistematis berdasarkan analisis kebutuhan dan tujuan yang telah ditetapkan. Model

${ }^{17}$ Jack C. Ricard, Curriculum Development in Language Teaching,h.3-4 
proses kurikulum Taba (dalam Richards) terdiri dari: diagnosa kebutuhan, rumusan sasaran, pemilihan bahan ajar, penyusunan bahan ajar, pemilihan pengalaman belajar, penyusunan pengalaman belajar, menentukan apa yang harus dievaluasi". ${ }^{18}$ Dalam pengajaran bahasa, perumusan tujuan dan pemilihan bahan ajar biasanya disebut desain silabus. Silabus merupakan spesifikasi rancangan pembelajaran dan harus dibuat dengan jelas dan tepat untuk mengetahui apa yang harus dilakukan dan apa yang tidak serta standar pencapainnya.

\section{d. Metodologi}

Metodologi

pembelajaran merupakan aktifitas dan pengalaman mengajar yang dipilih guru untuk mencapai tujuan proses pembelajaran. Aktifitas yang dilakukan guru tersebut didasarkan pada tujuan apa yang akan dicapai dan bahan ajar apa yang disampaikan. Komponen utama dalam metodologi pembelajaran adalah bagaimana guru memposisikan perannya dalam proses pembelajaran bahasa. Richards mengidentifikasi 8 peran guru dalam pembelajaran bahasa yaitu : pengawas belajar peserta didik, motivator, pengontrol dan pembentuk perilaku peserta didik, penyaji model bahasa yang akurat, pembimbing dan teman, penganalisis kebutuhan, pengembang materi ajar dan evaluator" ${ }^{19}$

\section{e. Tes dan Evaluasi}

Weir dan Roberts (dalam Richards)

\footnotetext{
${ }^{18}$ Jack C. Ricard, Curriculum Development in Language Teaching, h. 8

${ }^{19}$ Jack C. Ricard, Curriculum Development in Language Teaching h.12
}

membedakan antara dua tujuan utama evaluasi program bahasa yaitu pengembangan program danakuntabilitas program". ${ }^{20}$ Akuntabilitas mengacu pada segala yang terkandung dalam sebuah program pembelajaran yang berkenaan dengan kualitas atau mutu. Evaluasi yang berorientasi pada akuntabilitas (accountability-oriented evaluation) biasanya menguji pengaruh sebuah pembelajaran bahasa yang hasilnya digunakan untuk kepentingan stakeholder. Sebaliknya, evaluasi yang berorientasi pada pengembangan (development-oriented evaluation) dirancang untuk meningkatkan kualitas sebuah pembelajaran dengan mengukur proses yang sudah diterapkan.

\section{Mendesain Pembelajaran Bahasa Arab Untuk Anak Usia Dini}

Masa usia dini merupakan masa yang pendek tetapi merupakan masa yang sangat berarti bagi kehidupan anak manusia. Mengapa, karena dimasa ini semua potensi anak akan berkembang dengan cepat. Usia dini merupakan masa eksplorasi, masa imitasi, masa bermain, masa peka dan masa trozt alter 1 ( masa membangkang tahap 1). ${ }^{21}$ Karena anak usia dini memiliki karakteristik yang unik dalam belajar. Untuk itu perlu diperhatikan beberapa prinsip pembelajaran anak usia dini yang dapat dijadikan acuan dalam mendesain pembelajaran bahasa Arab.

Prinsip dasar dalam pembelajaran anak usia dini adalah (1) bermain sambil

\footnotetext{
${ }^{20}$ Jack C. Richards, Curriculum Development in Language Teaching h.288

21 Trianto Ibnu Badar al-Tabany, Desain Pengembangan Pembelajaran Tematik Bagi Anak Usia Dini ( Jakarta: Prenadamedia Group, cet ke:3, 2015) h.7
} 
belajar atau belajar seraya bermain.kegiatan pembelajaran disiapkan oleh guru hendaknya dilakukan dalam situasi yang menyenangkan dengan menggunakan strategi, metode, materi/bahan dan media yang menarik serta mudah diikuti anak (2)pembelajaran berorientasi pada perkembangan anak. Anak merupakan individu yang unik maka perlu memperhatikan perbedaan secara indiviudal (3)pembelajaran berorientasi pada kebutuhan anak. Anak usia dini sedang membutuhkan proses belajar untuk mengoptimalkan semua aspek perkembangannya. (4) stimulasi terpadu. Perkembangan anak besifat sistematis, progresif dan berkesinambungan. Hal ini berarti kemajuan perkembangan satu aspek akan memengaruhi aspek perkembangan lainnya. Karakteristik anak memandanag segala sesuatu sebagai suatu keseluruhan, bukan bagian demi bagian. Maka stimulasi harus diberikan secara terpadu sehingga seluruh aspek perkembangan dapat bekembang secara berkelanjutanm dengan memerhatikan kematangan dan konteks sosialdan budaya setempat. (5) lingkungan kondusif. Lingkungan belajar anak usia dini harus diciptakan sedemikian menarik dan menyenangkan serta demokratis sehingga anak selalu betah dalam lingkungan sekolah baik didalam maupun diluar ruangan. (6) menggunakan pendekatan tematik, kegiatan pembelajaran dirancang dengan menggunakan pendekatan tematik sebagai wadah mengenalkan berbagai konsep untuk mengenal dirinya dan lingkungan sekitar. (7) aktif, kreatif, inovatif, efektif dan menyenangkan.
Proses pembelajaran ini disiapkan oleh pendidik melalui kegiatan-kegiatan menari yang menarik dan menyenangkan untuk mengembangkan rasa ingin tahu anak, memotivasi anak untuk berpikir kritis dan menemukan hal-hal baru. (8) menggunakan berbagai media dan sumber belajar untuk menstimulasi perkembangan potensi anak. (9) mengembangkan kecakapan hidup melalui penyiapan lingkungan belajar yang menunjang berkembangnya kemampuan menolong diri sendiri. disiplin dan sosialisasi serta memperoleh keterampilan dasar yang berguna untuk kelangsungan hidupnya. (10) pemanfaatan teknologi informasi untuk kelancaran kegiatan (11) pembelajaran bersifat demokratis. ${ }^{22}$

Berdasarkan prinsip-prinsip pembelajaran anak usia dini dan konseptual pengembangan pembelajaran bahasa dapat dilakukan langkah awal mendesain pembelajaran bahasa Arab yaitu dengan membuat peta konsep. Peta konsep dibuat dengan mengacu pada kebutuhan bahasa Arab peserta didik dan guru. Dari hasil analisis kebutuhan tersebut kemudian ditentukan 5 - 10 tema, kemudian menyusun tema-tema tersebut dalam bentuk gambar lalu menghubungkan tema-tema tersebut dengan garis dan memberi lebel. Tema digunakan pada pembelajaran anak usia dini untuk membangun pengetahuan dan mengembangkan seluruh aspek perkembangan anak usia dini. Dalam mengembangkan tema yang terpenting harus dilakukan untuk membangun pengetahuan secara sistematik dan holistik. Prinsip pemilihan tema dalam pengenalan bahasa Arab yaitu:

${ }^{22}$ Ibid h. 75-76 
- Tema yang bersifat dasar dan selalu dapat dikembangkan

- Tema yang dihubungkan dengan suatu pristiwa / kejadian

- Tema yang dihubungkan dengan minat anak

- Tema yang dihubungkan dengan hari-hari besar

Tema-tema tersebut diajarkan tidak langsung terfokus pada penggunakan bahasa Arab melainkan diambil dari kata dasar yang sesuai dengan tema atau kata yang dipahami oleh anak. seperti: bunyi huruf, kosakata, bernyanyi dengan bahasa Arab, ungkapan sederhana.Pembelajaran sistem bunyi bahasa Arab secara praktis sangat penting sebagai pondasi berbicara, semakin baik penguasaan anak terhadap bunyi maka semakin baik dia akan mengucapkan kata secara alamiah.

Menurut Abdul Hamdi dalam mendesain pembelajaran bahasa Arab untuk anak usia dini diperlukan strategi berupa rencana, langkah dan sarana pembelajaran yang diperlukan dalam proses belajar mengajar dikelas. ${ }^{23}$ Strategi yang digunakan dalam mengajar bahasa Arab untuk anak usia dini yaitu:

\section{a. Bermain}

Bermain merupakan pendekatan dalam kegiatan anak usia dini dengan menggunakan strategi, metode, materi dan yang menarik agar anak mudah memahami dan diikuti oleh anak. dengan bermain anak dapat bereksplorasi,

\footnotetext{
${ }^{23}$ Abdul Hamdi dkk. Pembelajaran bahasa Arab : pendekatan, metode, strategi, materi dan media.(Malang: UIN MalangPress, 2008) h. 5
}

menemukan, memanfaatkan dan mengambil kesimpulan. Bermain juga dapat mengembangkan psiko-motorik anak. misalnya dalam pembelajaran bahasa Arab dapat dilakukan dengan permainan seperti tema kebersihan. Anak anak dapat bermain balok dengan menyusun huruf hijjayah, fuzzel dengan menyusun dan menyebutkan huruf atau angka hijjayah, flash card dengan memperkenalkan huruf huruf hijayah ini akan mengembangkan kecerdasaan pada anak.

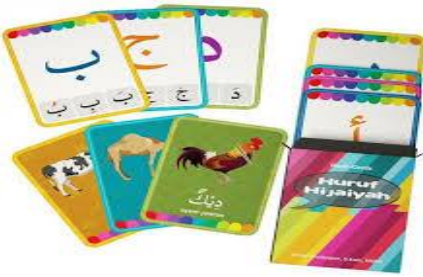

Gambar flash card

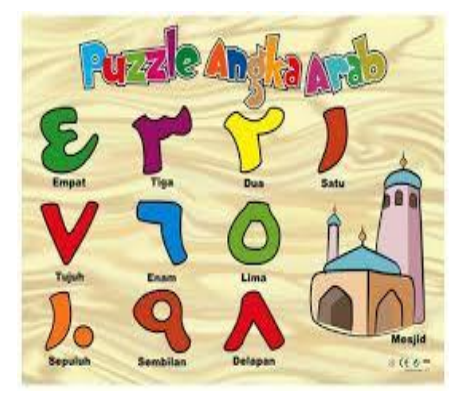

Gambar fuzzel

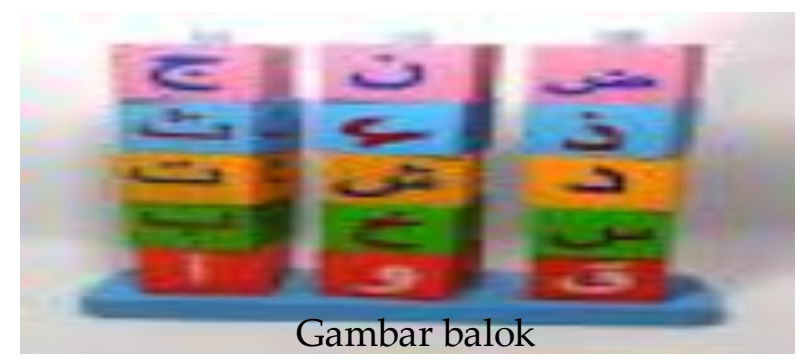

Kegiatan lainya anak dapat diajak bermain peran. Misalnya dengan judul " membersihkan rumah". Ibu dapat bertugas memasak, ada anak bertugas mencuci piring dan ada ayah yang menyapu lalu anak diminta mengambil kosakata yaitu kosakata 
peran, kosakata kerja, dan kosakata benda. Lalu kosakata dilafakan berulangulang oleh pendidik kemudian anak mencontohkan dan menirukan dengan tutur dan tindakan.

Kosakata dengan nilai karakter

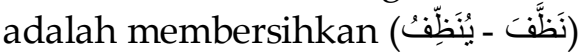

\begin{tabular}{|c|c|}
\hline Objek & Pekerjaan \\
\hline إِبْنَةُ & $\begin{array}{l}\text { Mencuci piring = } \\
\text { تَنْفِيْنِ الصَّحْنِ }\end{array}$ \\
\hline Ayah = أَبٌْ & Sنَسنَ - يَكْنِسن = Menyapu \\
\hline 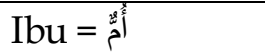 & Memasak = طَبَحَ - يَطْبَحُ \\
\hline
\end{tabular}

b. Bernyanyi

Kegiatan bernyanyi adalah salah satu metode yang mendukung perkembangan bahasa pada anak apabila ditekankan pada perkembangan bahasa. Kegiatan bernyanyi adalah kegiatan yang menyenangkan buat mereka. Satu demi satu kosakata diperkenalkan saat beernyanyi dengan melakukan gerakan sehingga mereka paham makna dari bahasa yang mereka ucapkan. Dengan bernyanyi anak diajak mengeja kosakata baru. Dengan nyanyian, pembendaharaan kata yang mendukung nilai karakter, kreativitas dan daya pikir pada perkembangan kognitifnya akan berkembang dengan baik.

Kegiatan pembelajaran bahasa dapat dimulai dengan pendidik menyampaikan tema "teladan rasullullah". Pendidik akan mempraktikkan langsung nyanyian tersebut. Lalu pendidik akan mengulang perkata, setelah itu pendidik mengajak anak menirukan nyanyian sampai anak bisa menirukan secara sempurna.

Penekanan kosakata dengan nilai karakter adalah jujur ( صديق), dipercaya (
انة (ماطنة ( dan menyampaikan Nyanyian dengan nilai karakter :

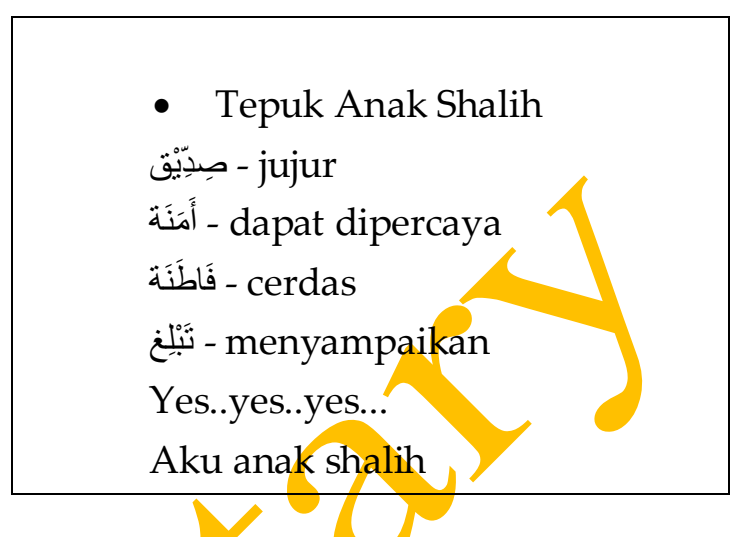

c. Mendongeng atau bercerita

Menurut Hurlock dalam faida nur'ani mengunkapkan masa kanak-kanak adalah usia yang paling tepat untuk mengembangkan keperibadian. Anak-anak sangat peka terhadap rangsangan yang berkaitan dengan aspek fisikomotor, intelek, sosial, emosi dan bahasa. ${ }^{24}$ Ada amanah yang banyak dalam mendongeng seperti mandiri, bersyukur, peduli lingkungan, pemberani, saling menyayangi, cinta damai, jujur, sabar, bersedekah semua terkandung dalam nilai karakter.

Kegiatan bercerita, pendidik mengajak murid untuk duduk melingkar kemudian pendidik memperkenalkan alat praga yang akan digunakan untuk bercerita. Lalu pendidik menyiapkan sebuah kotak kosakata yang merujuk pada nilai karakter, anak-anak mendengarkan cerita dengan menggunakan alat peraga lalu anak diminta untuk menemukan dalam kotak kosakata dengan gambar atau benda-benda yang sudah tertulis kosakata. Kosakata kata yang didapat akan diucapkan bersama seluruh peserta didik di kelas.

\footnotetext{
${ }^{24}$ Faida Nur'aini. Membentuk karakter anak dengan mendongeng. (solo: indeparent, 2011) h. 71.
} 
Misal tema adalah "cinta tanah air"

\begin{tabular}{|c|c|}
\hline Peraga & tosakata \\
\hline mbar bendera & لِِوَاءُ \\
\hline mbar pancasila & بَانْجَاسِيْلَاً \\
\hline $\begin{array}{l}\text { mbar/fotopresiden dan } \\
\text { wakil presiden }\end{array}$ & رَبَيْنسنُ الْجُمْهُهْ \\
\hline
\end{tabular}

d. Menggambar

Dengan menggambar anak akan berimajinasi dan berkreasi sesuai dengan keinginan anak. menggambar merupakan media perkembangan psikomotorik dan membuat anak menyenangkan.Pendidik menentukan, menyiapkan pola gambar dengan menentukan gambar sesuai nilai karakter, anak mengambil krayon berwarna-warni. Lalu pendidik menjelaskan isi pola gambar, kemudian anak berimajinasi dan menjadikan penjelasan pendidik sebagai tindakakan anak bersama-sama dalam proses mewarnai gambar/dan saling bekerjasama untuk menyelesaikan.

Contoh media gambar dengan tema " kerjasama"

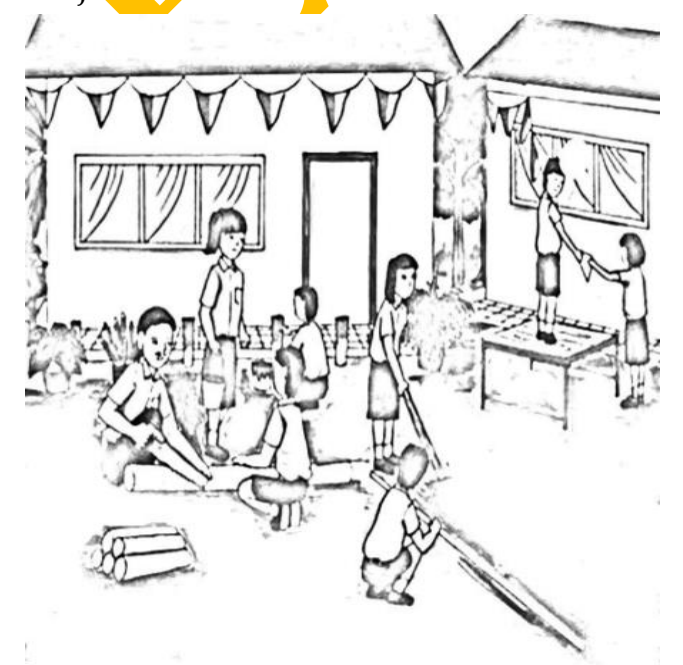

e. Pola tanda

- Kerjasama

Tanda ini merupakan simbol visual yang dapat dilihat langsung oleh anak. kemudian anak akan melihat, memperhatikan dan menirukan sehingga anak dapat memahami gambar dan kata. Kegiatan pembelajaran bahasa Arab dengan pola tanda digunakan untuk menjelaskan nilai karakter.

Contoh gambar dengan tema "kebersihan"

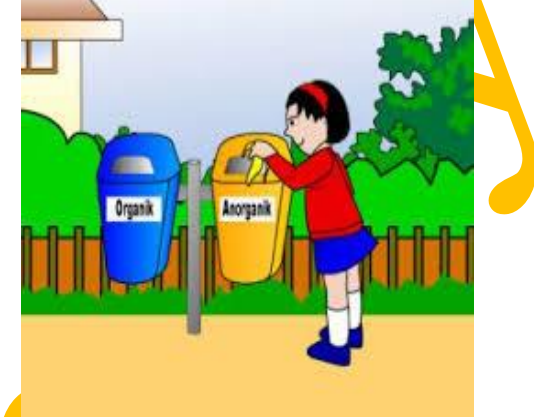

Kemudian ditulis plat atau papan النَََّافَةُ مِنَ

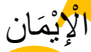

Contoh gamabar dengan tema "gemar membaca"

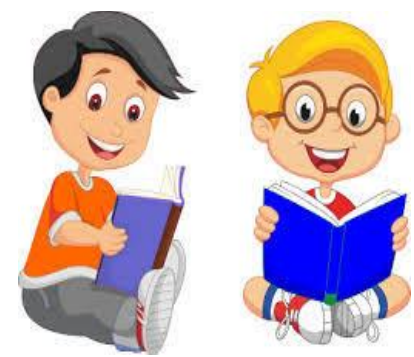

Kَرَ - يَقْرَاُ - membaca

\section{Penutup}

Anak usia dini merupakan periode emas (golden ages). Fakta menjelaskan periode emas ini dimana semua potensi anak berkembang paling cepat. Karena Salah satu periode yang sangat penting sebagai penanda anak usia dini adalahHasil penelitian di bidang neurologi mengatakan bahwa $80 \%$ kapasitas kecerdasan anak terbentuk dalam kurun waktu empat tahun pertama sejak kelahirannya. Kondisi inilah kemudian menjadi dasar pemikiran mengapa pembelajaran bahasa Arab sebaiknya sudah mulai diajarkan pada anak usia dini dengan tidak melupakan penanaman nilai-nilai karakter didalamnya. 
Diharapkan pembelajaran bahasa Arab dapat sebagai rangsangan kognitif anak hingga anak dapat meniru dan mencontohkan dengan tindakan sebagai rangsangan kognitif, afektif, psikomotor. Lalu diverbalkan dan diucapkan anak sebagai rangsangan bahasa yang akan dikembangkan pada kemampuan sosial dalam bertingkah laku dan mengembangkan imajinasi anak dengan memunculkan bahasa baru pada anak.

\section{Daftar Pustaka}

Djiwandono, M. Soenardi. Tes bahasa dalam pengajaran. (Bandung: ITB, 2008).

Gagne, Robet \& M. Leslie J. Briggs. Principles of Intuctional Design, Second Edition (New York: Holt And Wiston, 1979).

Hamdi, Abdul dkk. Pembelajaran bahasa Arab: pendekatan, metode, strategi, materi dan media. (Malang: UIN Malang Press, 2008).

Hartati, Sofia. How To Be a Good Teacher and To Be a Good Mother. (Jakarta: Enno Media, 2007).

Keraf, Gorys. Diksi dan Gaya Bahasa. (Jakarta: Gramedia)

Nation, I.S.P. and John Macalister. Language Curriculum Design (New York; Routledge, 2010).
Nunan, David. Language Teaching Methodology. (New York: Prentice Hall)

Nur'aini, Faida. Membentuk karakter anak dengan mendongeng. (Solo: Indeparent, 2011).

Pusat kurikulum departemen pendidikan nasional. Bahan pelatihan penguatan pembelajaran berdasarkan nilai nili-nilai budaya dan karakter bangsa, 2010).

Ricard, Jack C. Curriculum Development in Language Teaching, (New York, Cambridge University Press, 2001).

--.- The Language Teaching Matrix (New York, Cambridge University Press, 1990).

Susanto, Ahmad. Perkembangan Anak Usia Dini; Pengantar dalam Berbagai Aspeknya. (Jakarta: Kencana Prenada Media Group, 2011).

Tomlinson, Brian. Developing Materials For Language Teaching (London, Cromwell Press, 2003).

Vacca, Jo Anne L.Richard T Vacca \& Marry $\mathrm{K}$. Gove. Reading and learning to read. (Boston: Little Brown \& Company, 1987).

Zubaidi. Desain pendidikan karakter: konsepsi dan aplikasinya dalam lembaga pendidikan. (Jakarta: Kencasana, 2011). 